\title{
STUDY OF KINETICS MODEL OF FLAVONOID TOTAL RELEASE IN PATCH OF ANTIHYPERTENSIVE HERBS
}

\section{Dian Eka Ermawati*), Anif Nur Artanti, Dyah Ayu Ambarwati, Niken Rosyana Dewi Septini, Sholichah Rohmani, Wisnu Kundarto}

\author{
Department of Pharmacy, Faculty of Mathematics and Natural Sciences, \\ Sebelas Maret University, Surakarta, Indonesia
}

Received November 12, 2019; Accepted August 20, 2020

\begin{abstract}
The liquid extract of antihypertensive herbs could reduce blood pressure equivalent to Hydrochlorothiazide $25 \mathrm{mg}$ based on research conducted in "Hortus Medicus" clinic, Tawangmangu, Central Java, but parameters of herbal medicine taste, design, and packaging had the lowest scores. Transdermal patch was chosen as an alternative to resolve those problems. Polymers determined the effectiveness of the active substance release from the formula. Patch was formulated from combination of hydrophilic hydroxy methylcellulose (HPMC) and carboxymethylcellulose natrium (CMC-Na) polymer which would produce a fast release profile. The objective of this research was to study the kinetics models of total flavonoid release and to study the total number of flavonoids released from the antihypertensive herbs patch for 5 hours, as well as to determine the optimum formula for observing the weight, $\mathrm{pH}$ and loss on drying. Herbs were infused with distilled water at $90^{\circ} \mathrm{C}$ for 15 minutes, filtered then evaporated. Release kinetics model used a modified type-5 dissolution apparatus equipment with a cellophane membrane. The optimum proportion of HPMC and CMC-Na was 220:180 mg. Patch was dark brown, circle shaped, moist and flexible. It had $\mathrm{pH}$ value of $7.29 \pm 0.09$, folding endurance of $>350$, and thickness of $0.64 \pm 0.05 \mathrm{~mm}$. The average percentage of total flavonoids released from the matrix patch was $37.23 \%$ for 5 hours. The release kinetics followed the Higuchi kinetics model with a diffusion mechanism.
\end{abstract}

Keywords: antihypertensive herbs; CMC Na; HPMC; kinetics model; patch.

\section{INTRODUCTION}

Jamu is Indonesian's herbal medicine which was a cultural heritage used by Indonesian people as a treatment for diseases. This study used antihypertensive herbal medicine because hypertension was a disease with a relatively high prevalence compared to other non-contagious diseases that was equal to $64.83 \%$ in Indonesia as especially in Central Java (Central Java Provincial Health Office, 2018). Antihypertensive herbs consist of six herbs including Centella asiatica (L) Urb, Apium graveolens L, Orthosiphon arisatus, Phyllantus niruri L., Curcuma longa L, and Curcuma xanthorrhiza Roxb. The Center for
Research and Development of Medicinal Plants and Traditional Medicines (B2P2TOOT)has combined these 6 plants into antihypertensive herbs to treat hypertensive diseases. Antihypertensive herbs medicine was usually formulated into liquid and capsules. However, it has been tested in the process of scientific verification and was used for treatment at the "Saintifikasi Jamu Hortus Medicus" Clinic, Tawangmangu. Oral preparations were usually not practical for geriatrics patients who have difficulty swallowing, and some people do not like the odor or taste of herbal medicine. The parameters of herbal medicine taste, design, 
and packaging in scientific assessment of antihypertensive herbs of Hortus Medicus Clinic in B2P2TOOT had the lowest score (Maryani et al., 2017).

Transdermal patch was chosen as an alternative dosage form to overcome the problems of liquid medicinal herbs because patch was easily applied, did not cause pain, could be given for extended period of time, and reduced the frequency of doses (Alam et al., 2013). The main component in formulating transdermal patch is polymers. The properties of the polymer could control the rate of drug release and patch adhesion to the skin (Jhawat et al., 2013). The patch that was made by combination of hydrophilichydrophilic polymer such as HPMC and Sodium CMC showed faster drug release of $39.38 \%$ for 24 hours and $75 \%$ for 48 hours (Prabhu, et al., 2011) compared to patch which was formulated with a combination of hydrophilic-lipophilic. This research was carried out by optimizing patch matrix formulas that have been optimized in other studies using a combination of HPMC and CMC $\mathrm{Na}$ polymers with a total flavonoid model contained in water extracts of six herbs combination. In vitro tests of patch formulation covered in vitro drug release and permeation tests (Jhawat et al., 2013). Release test aimed to determine the amount of each active substance that could be released from the patch matrix that had been made (Ginting, 2014).

In vitro testing of the release and permeation of a drug preparation was carried out to describe the performance of a drug preparation product (Ueda et al., 2009). The performance of this product was used to determine the ability of a patch matrix base in releasing total flavonoids so that researchers would conduct an in vitro test. The in vitro method had advantages over the in vivo method in which it could be completed faster and avoided the use of test animals (Bravo Osuna et al., 2007). Based on the above statement, an in vitro release test was carried out with a total flavonoid model in a combination of liquid extract from Centella asiatica (L) Urb, Apium graveolens L,
Orthosiphon arisatus, Phyllantus niruri L., Curcuma longa L, and Curcuma xanthorrhiza Roxb. The release profile and the kinetics model of total flavonoid release patch preparations can be determined from the in vitro release test.

\section{METHODS \\ Materials}

A. graveolens Herb, C. Asiatica leaves, $P$. niruri Herb, $O$. aristatus leaves, $C$. longa Roxb, and C. xanthoriza Roxb (B2P2TOOT, Tawangmangu, Central Java, Indonesia), HPMC (Hercules Tianpu Chemicals Company Limited, China), Sodium CMC (Changshu Wealthy Science and Technology Company Limited, China), PEG 400 (Repacking by Bratachem, Indonesia), propilen glikol (Repacking by Bratachem, Indonesia), ethanol 96\% (Repacking by Bratachem, Indonesia), metanol pro analysis (SmartLab, Indonesia), potasium dihydrogen posphate (Merck KGaA, German), and $\mathrm{HCl}$ (JT Baker, Pennsylvania) were used as the materials in completing this research.

\section{Plants determination}

Determination of plants was carried out by the Center for Research and Development of Medicinal Plants and Traditional Medicines (B2P2TOOT), Tawangmangu, Central Java, Indonesia.

\section{Liquid extract of antihypertensive herbs}

Dried herbs were crushed using a blender and then sieved using a 30-mesh number sieve. Dried herbs powder weighed $37.5 \mathrm{~g}$ of A. graveolens; $22.5 \mathrm{~g} \mathrm{C}$. of Asiatica leaves, $22.5 \mathrm{~g}$ of $P$. niruri Herb; $22.5 \mathrm{~g}$ of $O$. aristatus leaves; $22.5 \mathrm{~g}$ of turmeric; and $22.5 \mathrm{~g}$ of ginger rhizome. The lower infusion pan was filled with water while the top one was filled with distilled water for as much as 2.5 liters (Triyono et al., 2017). The dried herbs powder was put into the top infusion pan, then the infusion pan was heated on the stove. The powder was stirred evenly until it was mixed with water. Infundations process of herbs during 15 minutes, start from the time when the temperature reached $80^{\circ} \mathrm{C}$, then filtered using a flannel. The filtered liquid extract was evaporated onto the water bath at temperature 
maintained around 50-60 ${ }^{\circ} \mathrm{C}$. The liquid extract was evaporated until hers extract became thick.

\section{Antihypertensive herbs patch formulation and physical property test}

Patch formula was based on the optimum formula that has been optimized using a total flavonoid model of six herbs liquid extracts including Centella asiatica (L) Urb, Apium graveolens L, Orthosiphon arisatus, Phyllantus niruri L., Curcuma longa L, and Curcuma xanthorrhiza Roxb (Ermawati et al., 2020). The thick extract was obtained from the infusion of the six herbs combination. All components compiled into antihypertensive patch was weighed (Table 1).

HPMC and Sodium CMC were dissolved into hot water, then stirred until homogeneous. The mixture was added with PEG 400 and propylene glycol, and stirred until homogeneous. Nipagin was dissolved in ethanol $96 \%$, then poured into the mixture. The liquid extract was added to the mixture, and then stirred until homogeneous. The homogeneous mixture was poured into petri dish, then left for 1 day at room temperature. After one day conditioning, the patch was roasted at $40^{\circ} \mathrm{C}$ for 24 hours, and the dried patch was removed from the petri and stored.

Table 1. Patch formulas with variation of concentration of HPMC and Sodium CMC

\begin{tabular}{lccccc}
\hline \multicolumn{1}{c}{ Materials } & Formula 1 & Formula 2 & Formula 3 & Formula 4 & Formula 5 \\
\hline Extract Herbs & 0.350 & 0.350 & 0.350 & 0.350 & 0.350 \\
\hline HPMC & 0.220 & 0.210 & 0.200 & 0.190 & 0.180 \\
\hline CMC Na & 0.180 & 0.190 & 0.200 & 0.210 & 0.220 \\
\hline PEG 400 & 0.400 & 0.400 & 0.400 & 0.400 & 0.400 \\
\hline Propylene glycol & 0.300 & 0.300 & 0.300 & 0.300 & 0.300 \\
\hline Ethanol 96\% & 5.000 & 5.000 & 5.000 & 5.000 & 5.000 \\
\hline Nipagin & 0.010 & 0.010 & 0.010 & 0.010 & 0.010 \\
\hline Aquadest & 9.500 & 9.500 & 9.500 & 9.500 & 9.500 \\
\hline
\end{tabular}

The optimal formula was stored in a desiccator for 4 weeks to determine the effect of storage on the optimal formula. Tests were done in week 0 and week 4 . Those tests are elaborated as the following.

\section{Organoleptic Test}

Three patches were observed visually including their color, shape, and surface conditions (Nurahmanto et al., 2017).

pH test

Three patches were tested using $\mathrm{pH}$ meter. Patches were cut into $2 \times 2 \mathrm{~cm}^{2}$ and dissolved in $4 \mathrm{~mL}$ of distilled water for 2 hours, then $\mathrm{pH}$ was checked using $\mathrm{pH}$ meter (Nurahmanto et al., 2017).

\section{Weight Test}

Three patches were weighed using a digital scale, and then the average weight was calculated (Parivesh et al., 2010).

\section{Thickness Test}

The thickness of three patches was measured at four different points using a caliper, and then the average of thickness was calculated (Parivesh et al., 2010).

\section{Moisture Test}

Moisture testing was done gravimetrically using a moisture analyzer. A total of three patches were weighed on the device as their initial weight and heated at 105 ${ }^{\circ} \mathrm{C}$ until a constant weight (final weight) was obtained, and the percentage was shown to shrink the moisture content of patch matrix (Setyawan et al., 2014).

\section{Folding Endurance Test}

The folding endurance test for three patches was done by folding the patch many times in the same place until it was damaged or broken (Parivesh et al., 2010). 


\section{Total flavonoid release test from patch}

Preparation of phosphate buffer solution $\mathrm{pH}$ $7.4 \pm 0.05$

Potassium dihydrogen phosphate $\left(\mathrm{KH}_{2} \mathrm{PO}_{4}\right)$ liquid of $50 \mathrm{~mL}$ was obtained from 27.2 grams of $\mathrm{KH}_{2} \mathrm{PO}_{4}$ dissolved in $1000 \mathrm{~mL}$ of distilled water. Take of $0.2 \mathrm{~mL}$ buffer stock solution was taken to a $200 \mathrm{~mL}$ volumetric flask and added with $39.1 \mathrm{~mL}$ of $0.2 \mathrm{M} \mathrm{NaOH}$ obtained from 8.0 grams of $\mathrm{NaOH}$ dissolved in $1000 \mathrm{~mL}$ of distilled water.

Stock solution of total flavonoid in phosphate buffer solution $\mathrm{pH} 7.4$

Quercetin powder was weighed for 10.0 $\mathrm{mg}$ and dissolved with $10 \mathrm{~mL}$ methanol solution into measuring flask (stock I). Stock solution I was taken in the amount of $10 \mu \mathrm{L}$ and dissolved with $10 \mathrm{~mL}$ of phosphate buffer solution of $\mathrm{pH} 7.4$ into measuring flask (Stock II).

Total flavonoid calibration curve in phosphate buffer solution $\mathrm{pH} 7.4$

Maximum wavelenght of quercetin of stock II solution then read using spectrophotometry UV-VIS at range of 200$500 \mathrm{~nm}$. Stock II solution was taken in the amount of $0.1 ; 1.5 ; 3.0 ; 4.5$; and $6.0 \mathrm{~mL}$ and dissolved with phosphate buffer $\mathrm{pH} 7.4$ into measuring flask ad $10 \mathrm{~mL}$. Serial solution was measured based on the absorption at the maximum wavelength of quercetin using spectrophotometer UV-Vis. Standard curve measurements were performed 3 times.

\section{Validation Analysis Method Linearity}

Calibration curve the measurement data of quercetin, then analyzed with linear regression so that the correlation coefficient (r) which showed linearity was obtained. The acceptable linearity value was $\geq 0.99$ (Miller and Miller, 2005).

Limit of detection (LOD) and limit of quantitation ( $L O Q)$

Limit of detection and limit of quantitation were determined from the standard curve regression obtained. Based on the residual standard deviation (SD) and slope (b) of the LOD and LOQ values could be calculated by Equations 1 and 2 (Miller and Miller, 2005).

$$
\begin{aligned}
& \mathrm{LOD}=\frac{3,3 \cdot S D}{b} \\
& \mathrm{LOQ}=\frac{10 \cdot S D}{b}
\end{aligned}
$$

\section{Determination of release test}

The total flavonoid release test from the patch was carried out using a type 5 dissolution test that was a paddle equipped with a diffusion disc. Before being tested, the membrane was immersed for \pm 12 hours in distilled water. The medium used was phosphate buffer solution $\mathrm{pH} 7.4 \pm 0.05$ for as much as $500 \mathrm{~mL}$ with a temperature of $37 \pm$ $0.5^{\circ}$ C. Discs that contained patches and membranes were inserted into the dissolution test and the paddle rotational speed was set at $100 \mathrm{rpm}$. Samples were taken for as much as $10 \mathrm{~mL}$ at $0 ; 15 ; 30 ; 45 ; 60 ; 90 ; 120 ; 150 ; 180$; 210; and 300 minutes. Each sample was added with a new $\mathrm{pH}$ of phosphate buffer of $10 \mathrm{~mL}$. The sample taken then determined for it was total flavonoid level by measuring the absorption at the maximum wavelength of quercetin with a spectrophotometer UV-Vis. Testing was replicated 3 times (Astuti, 2012).

\section{Determination of the release kinetics model and the release mechanism}

Determination of the release kinetics model and the release mechanism were determined using Microsoft Excel 2010. Linear regression line equations for each kinetics model were made in the following procedures (Reza et al., 2003):

1. Zero-order kinetics. Zero-order linear relationships were shown between the percentage of dissolved substance and time.

2. First-order kinetics. A first-order linear relationship was shown between the logarithm of the dissolved substance percentage and time. 3. Higuchi's kinetics model. The linear relationship of the Higuchi model was shown between the percentage of dissolved substance and the root of time.

4. Kinetics of the Kosmeyer-peppas model. The linear relationship of the Kosmeyerpeppas model was shown between the 
logarithm of the dissolved substance percentage and the logarithm of time. Determination of the release kinetics of a drug could be seen from the value of the correlation coefficient of the linear regression equation. Correlation coefficient ( $r$ ) was close to one. The release kinetics was considered to follow the release kinetics from the regression equation of the relevant kinetics model (Wicaksono et al., 2005).

\section{Data analysis}

The cumulative number of total flavonoids released and transported was determined based on the following Equation 3 (Sinko, 2006):

$$
Q=\frac{C n V+\sum^{n-1}{ }_{i=1} C i . S}{A}
$$

Where: $\mathrm{Q}=$ Cumulative number of total flavonoids per diffusion area $\left(\mu \mathrm{g} / \mathrm{cm}^{2}\right) ; \mathrm{Cn}$ $=$ total flavonoid concentration $(\mu \mathrm{g} / \mathrm{mL})$ in n- minute sampling; $\sum$ Ci.Ci $n-1 \mathrm{i}=1=$ Total flavonoid number $(\mu \mathrm{g})$ in the first sample (at n-minute) until before n-minute $n$; $\mathrm{V}=$ diffusion device volume $(\mathrm{mL}) ; \mathrm{S}=$ sampling volume $(\mathrm{mL}) ; \mathrm{A}=$ diffusion crosssectional area $\left(\mathrm{cm}^{2}\right)$.

\section{RESULTS AND DISCUSSION}

The results of the determination showed that six herbs used as research materials were
Centella asiatica (L) Urb, Apium graveolens L, Orthosiphon arisatus, Phyllantus niruri L., Curcuma longa L, and Curcuma xanthorrhiza Roxb. Determination of plant aims to ensure the legitimacy of the raw materials used in research. The yield of thick extract of antihypertensive herbs was $24.50 \%$. The percentage of yield indicates the maximum ability of the solvent to search for ingredients. Organoleptic observations showed thick and very thick black extract with a shrinkage of $28.26 \%$.

The equation obtained from the quercetin calibration curve in methanol was y $=0.0543 \mathrm{x}-0.0178$ with a correlation coefficient (r) of 0.9999. The equation was used to determine total flavonoid levels in extracts and patches. Total flavonoid level in viscous extract was $0.235 \pm 0.002 \% \quad(\mathrm{w} / \mathrm{w})$. The colour of patch preparation produced was dark brown because the colour of water extract was black. Patch has circular shape because it was printed on a Petri disk (Figure 1). Patches were relatively flexible due to the presence of PEG 400 as a plasticizer which could increase patch elasticity (Nurahmanto et al., 2017). The optimal patch formula had the best physical properties test value. Optimal formula with HPMC: CMC Na ratio of 220: $180 \mathrm{mg}$ would produce a response value approaching the target value of $98.2 \%$. Results of physical properties of optimum formula antihypertensive herbs patch compared with a research by Nurahmanto et al. (2017) were presented in Table 2.

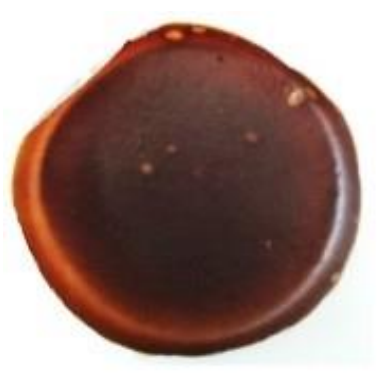

Figure 1. Results of physical appearance of optimum formula antihypertensive herbal patch 
Table 2. Test results of physical properties of optimum formula antihypertensive herbs patch

\begin{tabular}{lcc}
\hline \multicolumn{1}{c}{ Physical Characteristics } & Test Results & Standard \\
\hline pH & $7.29 \pm 0.09$ & $4-7.5$ \\
\hline Weigh (gram) & $1.45 \pm 0.02$ & - \\
\hline Thickness (mm) & $0.64 \pm 0.05$ & $\leq 1 \mathrm{~mm}$ \\
\hline Moisture Content (\%) & $34.60 \pm 2.90$ & $40 \% *$ \\
\hline Folding Endurance (times) & $>350$ & $>300$ \\
\hline *Results of standard product of Bye-Bye Fever ${ }^{\circ}$ & &
\end{tabular}

The maximum wavelength of quercetin obtained was $371 \mathrm{~nm}$. The linear regression equation obtained was $y=0.036 x-0.002$ with a correlation coefficient $(r)$ of 0.9996 that could be accepted. The absorbance produced increases with increasing series of concentrations. LOD and LOQ can be determined from the calibration curve regression. The LOD obtained was 0.018 $\mu \mathrm{g} / \mathrm{mL}$ while the LOQ was $0.556 \mu \mathrm{g} / \mathrm{mL}$. Figure 2 shows that the percentage of total flavonoids released increased relatively faster at the beginning of time at a non-constant speed and experienced a constant increase at 30 to 300 minutes. The average test result of total flavonoid percentage released during 5 hours were $37.23 \%$. These results were smaller than other studies that was equal to $75 \%$ for 5 hours (Surender et al., 2016).

The different results due to the differences of polymer that were used. In a study by Surender et al. (2016), he used Polyvinyl Pyrrolidone and HPMC. The Surender's results mentioned that the high concentration of HPMC relatively increased the drug release from polymer. In this study, researcher used sodium CMC and HPMC, where sodium CMC was a polymer that was commonly used for sustaining release preparations so that it may hold the active substance to release for 5 hours. However, the drug release still increased afterwards.

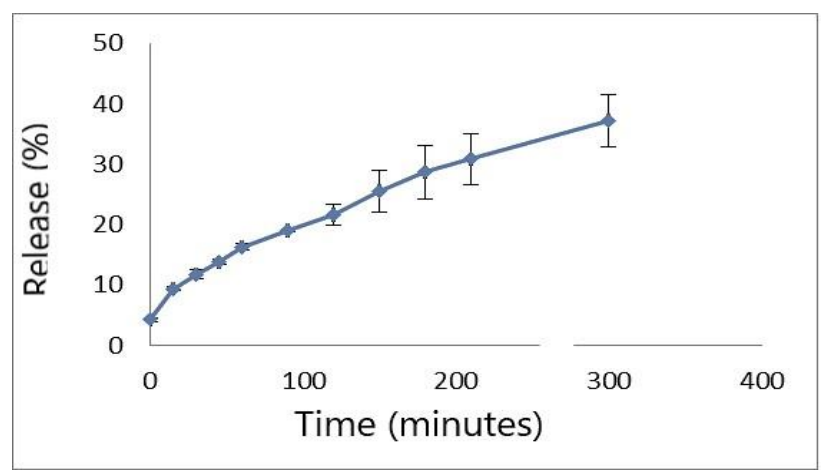

Figure 2. Graphics results of total flavonoid release from patch during 300 minutes

Determination of the kinetic model and mechanism of drug release aims to describe the characteristics of drug release. Determination of the drug release kinetic model could be obtained from the Higuchi equation, zero order, first order, and
Korsmeyer-Peppas using Microsoft Excel. The results of the release data obtained were then applied into the equation of the mathematical model of drug release kinetics. The release kinetics results were presented in Table 3.

Table 3. Results of total flavonoid release kinetics with kinds of kinetic drug release models

\begin{tabular}{|c|c|c|c|c|c|c|c|c|}
\hline \multirow{2}{*}{ Dosage Forr } & \multicolumn{2}{|c|}{ Zero Order } & \multicolumn{2}{|c|}{ One Order } & \multicolumn{2}{|c|}{ Higuchi } & \multicolumn{2}{|c|}{ Korsmeyer Peppas } \\
\hline & $\mathbf{r}$ & $\mathbf{k}_{\mathbf{0}}$ & $\mathbf{r}$ & $\mathbf{k}_{1}$ & $\mathbf{r}$ & $\mathbf{k}_{\mathbf{h}}$ & $\mathbf{R}$ & $\mathbf{k}_{\mathbf{k p}}$ \\
\hline Patch & 0.983 & 0.106 & 0.879 & 0.001 & 0.992 & 1.954 & 0.986 & 2.421 \\
\hline
\end{tabular}


Table 3. shows that the kinetics of total flavonoid release from the patch could be accepted with $r \geq 0.99$, in which it was obtained for 0.992 in this particular case. The kinetics model in this study follows the Higuchi model because the $r$ obtained in the Higuchi model was higher than the other models. These results indicate that the mechanism of total flavonoid release from the patch was through a diffusion process in which the total flavonoids that was released over time would be released at a low speed. Figure 3 shows that the data distribution points was relatively close to linear lines so that the kinetic model follows the Higuchi kinetics model. The equation obtained from the release kinetics is $\mathrm{y}=1.9542 \mathrm{x}+$ 1.7885 .

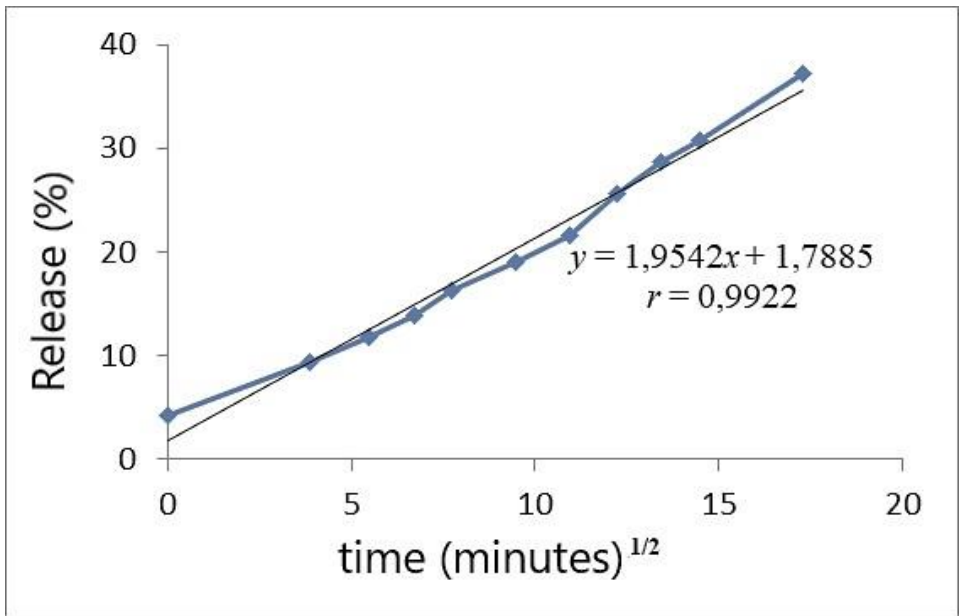

Figure 3. Results of kinetic graph of the total flavonoid release of the Higuchi model during 5 hours.

\section{CONCLUSION}

The optimum formula of patch with a combination of polymer HPMC and Sodium CMC (220: $180 \mathrm{mg}$ ) was able to release total flavonoids on average of $37.23 \%$ for 5 hours with the Higuchi release kinetics model and the diffusion release mechanism.

\section{ACKNOWLEDGEMENT}

(Lembaga Penelitian dan Pengabdian Masyarakat) Universitas Sebelas Maret, Surakarta, Indonesia 2019.

\section{REFERENCES}

Alam, M.I., Alam, N., Singh, V., Alam, M.S., Ali, M.S., Anwer, T., et al., 2013. Type, Preparation and Evaluation of Transdermal Patch: A Review, World Journal of Pharmacy and Pharmaceutical Sciences, 2(4), 2206-2210.

Astuti, E.J., 2012. Pelepasan Flavonoid Gendarusa vulgaris Nees dari Matriks Sediaan Param Fraksi Etanol 60\% dan
Param Fasa Air. Jurnal Farmasi dan Kesehatan, 2(1), 1-9.

Bravo-Osuna, I., Vauthier, C., dan Ponchel, G., 2007. Drug Delivery Research Advance, Chapter 2: Core-Shell Polymer Nanoparticle Formulation for the Oral Administration of Peptides and Proteins. Nova Science Publishers, Inc., New York, pp. 51-62

Departemen Kesehatan Republik Indonesia. 2014., Farmakope Indonesia edisi V. Departemen Kesehatan RI, Jakarta, pp. 1085-1086.

Departemen Kesehatan Republik Indonesia. 2000., Parameter Standar Umum Ekstrak Tumbuhan Obat. Jakarta, Direktorat Jendral Pengawasan Obat dan Makanan, pp. 10-11.

Ermawati, D.E., Ambarwati, D.A., Dewi, R.N., Artanti A.N., Rohmani S., Kundarto W. 2020. Optimization of hydroxymethylcellulose and sodium CMC of transdermal patch of antihypertension "Hortus Medicus" and transport through membrane using franz 
diffusion cell method: AIP Conference Proceedings 2237, 020063 - The 14th Joint Conference on Chemistry, 2019.

Ginting, D. 2014., Formulasi Patch Natrium Diklofenak Berbasis Polimer Hidroksi Propil Metil Selulosa (HPMC) dan Natrium Karboksi Metil Selulosa (Na CMC) sebagai Antiinflamasi Lokal pada Penyakit Periodontal. Fakultas Kedokteran dan Ilmu Kesehatan UIN Syarif Hidayatullah, Jakarta.

Jhawat, V.C., Saini, V., Kamboj, S., dan Maggon, N., 2013. Transdermal Drug Delivery Systems: Approaches and Advancements in Drug Absorption Through Skin, Int J Pharm Sci Rev Res, 20(1), 47-56.

Maryani, H., Kristiana, L., dan Lestari, W., 2017. Analisis Multiatribut Fishbein terhadap Jamu Saintifik (Studi Kasus di Balai Kesehatan Tradisional Masyarakat Makassar dan Puskesmas Colomadu I Karanganyar). Media Litbangkes, 27(2), 89-98.

Miller, J. and Miller, J., 2005. Statistics and Chemometrics for Analytical Chemistry 5th ed. Pearson Education Limited. Essex, pp. 203.

Nurahmanto, D., Sabrina, F.W., dan Ameliana, L., 2017. Optimasi Polivinilpirolidon dan Carbopol pada Sediaan Patch Dispersi Padat Piroksikam. Jurnal Ilmiah Manuntung, 3(2). 197-206.

Parivesh, S., Sumeet, D., and Abhishek, D., 2010. Design, Evaluation, Parameters and Marketed Products of Tansdermal Patches: A Review, Journal of Pharmacy Research, 3(2), 235-240.

Prabhu, P., Shah, S., and Gundad, S. 2011., Formulation Development and Investigation of Domperidone Transdermal Patches. International Journal of Pharmaceutical Investigation, 1(4), 240-246.

Reza, Md Selim., M.A. Quadir., dan S.S. Haider., 2003. Comparative Evaluation of Plastic, Hydrofobic, and Hydrophilic Polymers as Matrices for Controlled
Release Drug Delivery. Journal of Pharmaceutical Science, 6(2), 282-291.

Setyawan, E.I., Dewantara, I.G.N.A., dan Putra, I.M.D.P., 2014. Optimasi Formula Matrik Patch Mukoadhesif Ekstrak Daun Sirih (Piper betle L.) Menggunakan Mentol dan PEG 400 sebagai Permeation Enhancer dan Plasticizer. Media Farmasi, 11(2), 120- 132.

Surender, Verma., Vipul, M., dan Ashima., 2016. Formulation, Evaluation, and Optimization of Transdermal Patches of Losartan Potassium. World Journal Pharmaceutica Science, 4(5), 277-284.

Triyono, A., Rahmawati, N., dan Farida, S., 2017. Jamu Saintifik Suatu Lompatan Ilmiah Pengembangan Jamu, Karanganyar. Balai Besar Penelitian dan Pengembangan Tanaman Obat dan Obat Tradisional, pp. 14-27.

Triyono, A., Zulkarnain, Z., dan Mana, T.A., 2018. Studi Klinis Ramuan Jamu Antihipertensi pada Pasien Hipertensi Derajat I. Jurnal Kefarmasian Indonesia, 8(1), 17-25.

Ueda, C.T., Shah, V.P., Derdzinski, K., Ewing, G., Flynn, G., Maibach, et al., 2009. Topical and Transdermal Drug Products. Pharmacopeial Forum, 35(3), 750-764.

Wicaksono, Y., Hendradi, E., dan Radjaram, A., 2005. Analisis Proses Lepas Lambat $\mathrm{Na}$ Diklofenak dari Tablet Matrik Berbasis Etilselulosa Polivinilpirolidon K-30. Seminar Nasional MIPA, FMIPA UI, Depok, 7682. 